\title{
Optimasi Komposisi Lactobacillus bulgaricus dan Streptococcus thermophilus pada Yogurt Terfortifikasi Buah Lakum (Cayratia trifolia (L.) Domin) sebagai Antibakteri terhadap Escherichia coli
}

\section{Optimization of Composition of Lactobacillus bulgaricus and Streptococcus thermophilus in Yoghurt Fortified by Lakum Fruit (Cayratia trifolia (L.) Domin) as an Antibacterial Against Escherichia coli}

\author{
Ika Ristia Rahman, Nurkhasanah*, Ika Kumalasari \\ Fakultas Farmasi, Universitas Ahmad Dahlan, Yogyakarta, Indonesia
}

\section{ARTICLE HISTORY}

Received: January 2019 Revised: Juny 2019 Accepted: July 2019

\begin{abstract}
ABSTRAK
Optimasi komposisi Lactobacillus bulgaricus dan Streptococcus thermophilus pada yogurt terfortifikasi buah lakum (Cayratia trifolia (L.) Domin) sebagai antibakteri terhadap Escherichia coli telah dilakukan. Yogurt dibuat dengan memfermentasikan susu bubuk full cream dengan penambahan variasi kultur bakteri $L$. bulgaricus dan S. thermophilus, serta penambahan ekstrak buah lakum. Proses fermentasi sangat bergantung pada kultur bakteri yang digunakan. Penelitian ini bertujuan untuk mengetahui komposisi optimal bakteri L. bulgaricus dan S. thermophilus pada yogurt terfortifikasi buah lakum sebagai antibakteri pada E. coli. Penelitian dilakukan dengan cara memvariasikan komposisi bakteri L. bulgaricus dan S. thermophilus pada yogurt buah lakum. Analisis terhadap yogurt buah lakum dilakukan dengan pengujian stabilitas keasaman, $\mathrm{pH}$, kadar antosianin dan aktivitas daya hambat terhadap bakteri E.coli. Analisis data dilakukan dengan menggunakan MANOVA (Multivariate Analysis of Variance). Hasil penelitian menunjukan bahwa yogurt buah lakum dengan kombinasi L. bulgaricus dan S. thermophilus 2:1 (v/v) memberikan stabilitas yang baik selama penyimpanan dengan nilai keasaman yang meningkat dan $\mathrm{pH}$ yang turun. Kadar antosianin dalam yogurt selama penyimpanan mengalami penurunan dan yogurt plain (tanpa penambahan ekstrak buah lakum) dengan kombinasi L. bulgaricus dan $S$. thermophilus $2: 1(\mathrm{v} / \mathrm{v})$ memiliki daya hambat terhadap bakteri $E$. coli dengan nilai yang paling tinggi.
\end{abstract}

Kata kunci: optimasi; yogurt; Cayratia trifolia L; Lactobacillus bulgaricus; Streptococcus thermophilus; antibakteri; E.coli

\begin{abstract}
Optimization of composition of Lactobacillus bulgaricus and Streptococcus thermophilus in yoghurt fortified by lakum fruit (Cayratia trifolia (L.) Domin) extract as an antibacterial against Escherichia coli was investigated for the first time in this research. Yoghurt was made by fermenting milk with several compositions of $L$. bulgaricus and $S$. thermophilus as starter cultures and also adding lakum fruit extract as an antibacterial against $E$. coli. The fermentation process was depended on the bacterial culture used. The aim of the research was to determine the optimal composition of L. Bulgaricus and $S$. thermophilus bacteria in lakum fruit yoghurt as an antibacterial against $E$. coli. The research was done by making variation of composition of $L$. bulgaricus and $S$. thermophilus bacteria culture in lakum fruit yoghurt. Lakum fruit yoghurt was analysed with acidity stability test, $\mathrm{pH}$, anthocyanin level and inhibitory activity against $E$. coli. The data analysis was done with MANOVA (Multivariate Analysis of Variance). The results showed that lakum fruit yoghurt with composition of L. bulgaricus and $S$. thermophilus $2: 1(\mathrm{v} / \mathrm{v})$ had a good stability with increased acidity dan decreased $\mathrm{pH}$. The value of anthocyanin in lakum fruit yogurt decreased and plain yoghurt (without lakum fruit extract) with composition of L. bulgaricus and S. thermophilus $2: 1(\mathrm{v} / \mathrm{v})$ gave the highest inhibitory value against E. coli.
\end{abstract}

Keyword: optimization; yoghurt; Cayratia trifolia L; Lactobacillus bulgaricus; Streptococcus thermophilus; antibacteria; E.coli 


\section{PENDAHULUAN}

Menurut BPOM (2005), pangan fungsional adalah pangan olahan yang memiliki kandungan komponenkomponen fungsional yang secara ilmiah memiliki fungsi fisiologis, aman dan memiliki manfaat bagi kesehatan. Salah satu produk pangan fungsional adalah probiotik yang memiliki manfaat membantu mereduksi penyakit intestine (usus), mencegah diare pada anak yang terserang virus, mencegah infeksi bakteri dan khamir, serta meningkatkan fungsi sistem kekebalan dan mereduksi gejala alergi (Winarno \& Winarno, 2017). Yogurt merupakan pangan fungsional probiotik karena mengandung sejumlah bakteri hidup yang menguntungkan bagi kesehatan pencernaan dan merupakan pengembangan produk susu fermentasi yang berperan terhadap kesehatan manusia. Proses terjadinya fermentasi susu menjadi yogurt dibantu oleh bakteri asam laktat yang akan membentuk tekstur yang halus dan semi padat, serta membentuk rasa khas asam yang segar. Karakteristik bakteri yang digunakan pada pembuatan yogurt adalah bakteri penghasil asam laktat seperti Lactobacilli, Bifidobacteria dan Streptococcus thermophilus (Trachoo, 2002).

Kombinasi kultur starter yang biasa digunakan dalam pembuatan yogurt di antaranya adalah Lactobacillus bulgaricus dan Streptococcus thermophilus. Kedua bakteri tersebut dapat tumbuh bersama-sama secara simbiosis dan akan menghasilkan asam lebih banyak dari pada digunakan hanya salah satu saja. Kombinasi kultur starter Lactobacillus bulgaricus dan Streptococcus thermophilus digunakan karena kedua bakteri tersebut dapat saling mendukung pertumbuhan. Lactobacillus bulgaricus membantu memperpanjang fase logaritmik Streptococcus thermophilus dengan cara membebaskan peptida-peptida dari kasein susu yang merupakan perangsang untuk pertumbuhan Streptococcus thermophilus (Mitchel \& Sandine, 1984). Pemecahan laktosa menjadi asam laktat dan asam format yang dihasilkan oleh Streptococcus thermophillus menurunkan $\mathrm{pH}$ dan membuat suasana menjadi asam sehingga Lactobacillus bulgaricus dapat tumbuh dengan baik (Helferich \& Westhoff, 1980). Kombinasi komposisi dua starter tersebut harus dioptimalkan sehingga diperoleh yogurt dengan mutu yang sesuai Standar Nasional Indonesia (SNI) dan diterima oleh konsumen dari segi tampilan, bau dan rasa.

Pada pembuatannya, yogurt diberi bahan tambahan, seperti buah-buahan, untuk memperbaiki warna dan menambah aktivitas. Salah satu buah yang memiliki fungsi sebagai pewarna dan memiliki aktivitas antibakteri adalah lakum. Lakum (Cayratia trifolia (L). Domin) termasuk ke dalam famili vitaceae, seperti anggur biru (Vitis vinivera). Penelitian Sowmya et al (2015) menunjukkan bahwa ekstrak air buah lakum mengandung metabolit sekunder yang salah satunya adalah flavonoid. Senyawa yang banyak terdapat dalam flavonoid adalah antosianin. Antosianin memiliki aktivitas biologi seperti antiinflamasi, antioksidan, antikanker, dan antibakteri (Kumar et al., 2012). Menurut Neliyanti dan Idiawati (2014), ekstrak air buah lakum mengandung pigmen warna golongan antosianin yang stabilitasnya baik pada $\mathrm{pH}$ asam (pH 1 dan 2). Oleh karena itu, penelitian ini diharapkan dapat meningkatkan stabilitas antosianin buah lakum dalam produk yogurt yang memiliki nilai pH yang cenderung asam 4-4,5 (Buckle et al., 2007). Pada pembuatan yogurt, komposisi bakteri yang berperan dalam proses fermentasi akan berdampak pada mutu yogurt. Berdasarkan hal tersebut, tujuan penelitian ini adalah unttuk mengetahui komposisi optimal bakteri Lactobacillus bulgaricus dan Streptococcus thermophilus pada yogurt yang difortifikasi buah lakum sehingga mendapatkan yogurt dengan mutu yang sesuai dengan SNI dan memiliki daya antibakteri terhadap Escherichia coli.

\section{METODOLOGI}

\section{Alat dan Bahan}

Alat yang digunakan dalam penelitian ini adalah spektrofotometri UV-Visible type 1700 (Shimadzu $^{\circledR}$, Jepang), autoklaf (Hirayama ${ }^{\circledR}$, Jerman), oven $\left(\right.$ Memmert $^{\circledR}$, Jerman), laminar air flow (Haier ${ }^{\circledR}$, Cina), inkubator $\left(\mathrm{Memmert}^{\circledR}\right.$, Jerman) dan $\mathrm{pH}$ meter. Bahan dalam penelitian ini adalah ekstrak buah lakum (Cayratia trifolia (L) Domin) yang diperoleh dari Kecamatan Pematang Tujuh, Kabupaten Kubu Raya, Kalimantan Barat, susu bubuk full cream plain, biakan Streptococcus thermophilus (Fakultas Teknologi Pertanian, UGM), Lactobacillus bulgaricus (Fakultas Teknologi Pertanian, UGM) dan Escherichia coli (Fakultas Farmasi, UAD).

\section{Pembuatan Starter Bakteri}

Susu bubuk full cream $1,5 \mathrm{~g}$ dilarutkan dalam $10 \mathrm{~mL}$ air, dipasteurisasi pada suhu $85{ }^{\circ} \mathrm{C}$ selama 15 menit, kemudian didinginkan sampai suhu $40^{\circ} \mathrm{C} .1$ ose kultur hasil pembiakan dari media MRSB (deMan, Rogosa and Sharpe Broth) diinokulasikan pada susu yang sudah dipasteurisasi, lalu diinkubasi selama 24 jam dengan suhu $37{ }^{\circ} \mathrm{C}$. Masing-masing bakteri starter dipindahkan ke dalam $100 \mathrm{~mL}$ susu yang telah dipasteurisasi pada suhu $85{ }^{\circ} \mathrm{C}$ selama 10 menit dan kembali diinkubasi selama 24 jam pada suhu $37^{\circ} \mathrm{C}$. Masing-masing kultur starter siap digunakan.

\section{Pembuatan Ekstrak Lakum}

Buah lakum sebanyak 200 gram ditimbang, ditambahkan $200 \mathrm{~mL}$ aquadest, lalu dihaluskan dengan blender (perbandingan 1:1). Proses ekstraksi dengan pemanasan suhu $70{ }^{\circ} \mathrm{C}$ selama 120 menit, lalu ekstrak disaring (Neliyanti, 2014). 
Tabel 1. Formula pembuatan yogurt

\begin{tabular}{lllllll}
\hline & \multicolumn{7}{c}{ Formulasi yogurt $100 \mathrm{~mL}$} \\
\cline { 2 - 7 } & Y.Plain & Y.Plain & Y.Plain & Y.Lakum & Y.Lakum & Y.Lakum \\
& $1: 1$ & $1: 2$ & $2: 1$ & $1: 1$ & $1: 2$ & $2: 1$ \\
\hline Susu bubuk & & & & & & \\
full cream (13\% b/v) & $100 \mathrm{~mL}$ & $100 \mathrm{~mL}$ & $100 \mathrm{~mL}$ & $100 \mathrm{~mL}$ & $100 \mathrm{~mL}$ & $100 \mathrm{~mL}$ \\
Starter LB : ST (5\% v/v) & $1: 1$ & $1: 2$ & $2: 1$ & $1: 1$ & $1: 2$ & $2: 1$ \\
Ekstrak buah lakum $100 \%$ & 0 & 0 & 0 & $7.5 \mathrm{~mL}$ & $7.5 \mathrm{~mL}$ & $7.5 \mathrm{~mL}$ \\
\hline
\end{tabular}

Keterangan: $\quad$ LB : Lactobacillus bulgaricus

ST : Streptococcus thermophilus

\section{Pembuatan Yogurt}

Yogurt dibuat dengan 6 jenis formula. Masing-masing formula dengan volume $100 \mathrm{~mL}$ dapat dilihat pada Tabel 1. Proses pembuatan yogurt adalah sebagai berikut. Susu bubuk full cream, yang telah dipasteurisasi pada suhu $85{ }^{\circ} \mathrm{C}$ selama 10 menit, diturunkan suhunya sampai 40 ${ }^{\circ} \mathrm{C}$. Kemudian, susu diinokulasikan dengan starter, yang telah dibuat sebelumnya, sebanyak $5 \% \mathrm{v} / \mathrm{v}$. Setelah itu, campuran tersebut diinkubasi pada suhu $37^{\circ} \mathrm{C}$ selama 18 jam. Selanjutnya, ekstrak buah lakum ditambahkan dan diaduk sampai homogen, lalu yogurt disimpan dalam refrigerator pada suhu $5{ }^{\circ} \mathrm{C}$.

\section{Pengujian pH}

Pengujian $\mathrm{pH}$ dilakukan menggunakan $\mathrm{pH}$ meter. Sebelum pengukuran, $\mathrm{pH}$ meter harus dikalibrasi terlebih dahulu dengan larutan buffer $\mathrm{pH} 7$ dan 10. Ujung elektroda dari pH meter dicelupkan pada sampel yogurt. Nilai $\mathrm{pH}$ sampel yogurt tersebut akan ditunjukkan di layar $\mathrm{pH}$ meter (AOAC, 2000).

\section{Analisis Keasaman}

Pada pengujian asam tertitrasi, jumlah asam dihitung sebagai asam laktat. Pengujian menggunakan $\mathrm{NaOH}$ $0,1 \mathrm{~N}$ sebagai titran dengan titik akhir titrasi ditandai dengan perubahan warna larutan menjadi merah muda. Keasaman produk yogurt dinyatakan dalam persen yaitu antara 0,5-2\% (SNI, 2009).

Ket : $\mathrm{W}=$ Bobot sampel

$\mathrm{V}=$ Volume larutan $\mathrm{NaOH}$

$\mathrm{N}=$ Normalitas larutan $\mathrm{NaOH}$

$90=\mathrm{BM}$ (bobot molekul) asam laktat

$$
\text { Jumlah Asam }(\%)=\frac{\mathrm{V} \times \mathrm{N} \times 90}{\mathrm{~W}} \times 100 \%
$$

\section{Pengujian Total Antosianin Ekstrak Lakum}

Pengujian total antosianin ekstrak menggunakan metode $\mathrm{pH}$ differential. Sebanyak 20 gram yogurt disentrifugasi selama 45 menit, lalu supernatan diambil. Sebanyak
$25 \mathrm{mg}$ supernatan dimasukkan ke dalam labu ukur 25 $\mathrm{mL}$, kemudian ditambahkan larutan buffer kalium klorida $(0,025 \mathrm{M}) \mathrm{pH} 1$ sampai volume menjadi $25 \mathrm{~mL}$. Sebanyak $25 \mathrm{mg}$ supernatan dimasukkan ke dalam labu ukur $25 \mathrm{~mL}$ yang lain, kemudian ditambahkan larutan buffer natrium asetat (Sigma Aldrich) (0,4 M) pH 4,5 sampai volume menjadi $25 \mathrm{~mL}$. Kedua labu tersebut kemudian ditempatkan di tempat gelap selama 60 menit. Penyerapan sinar dari setiap larutan setelah mencapai kesetimbangan diukur dengan spektrofotometer UVVis pada panjang gelombang $700 \mathrm{~nm}$ dengan blanko air terdestilasi. Konsentrasi antosianin monomeric dinyatakan sebagai mg CyE (cyanidin-3-glucoside equivalent) per gram bahan kering sampel. Selanjutnya, antosianin monomeric (CyE) dihitung dengan menggunaan persamaan (1) dan (2) (Jie et al., 2013). Monomer antosianin dihitung dan dinyatakan sebagai ekuivalen sianidin-3-glukosida ( $\left.\mathrm{CyE}, \mathrm{C}_{21} \mathrm{H}_{21} \mathrm{O}_{11}, \mathrm{mg} / \mathrm{L}\right)$. Ket :

A = Nilai absorbansi atau serapan

$\mathrm{A}_{\lambda \text { vismax }}=$ Absorbansi pada panjang gelombang maksimum

$A=\left(A_{\lambda v i s m a x}-A_{700}\right)_{\mathrm{pH} 1.0}-\left(A_{\lambda v i s m a x}-A_{700}\right)_{\mathrm{pH} 4.5}$

Antosianin monomeric $\left(\mathrm{CyE}, \frac{\mathrm{mg}}{\mathrm{L}}\right)=\frac{\mathrm{A} \times \mathrm{BM} \times \mathrm{FP} \times 1000}{\varepsilon \times 1}$

$\mathrm{A}_{700}=$ Absorbansi pada panjang gelombang $700 \mathrm{~nm}$

$\mathrm{BM}=$ Bobot molekul antosianin $(449,2 \mathrm{Da})$

$\mathrm{FP}=$ Faktor pengenceran

$\varepsilon \quad=$ Absorbansi molar cyanidin-3-glucoside (26900)

\section{Pengujian Daya Hambat}

Kultur E. coli dibuat dalam suspensi media pengencer BPW (Buffer Peptone Water) 1\%. Sebanyak $1 \mathrm{~mL}$ suspensi E. coli diinokulasikan ke dalam 15-20 mL media Mueller Hinton Blood Agar (MH) ke dalam petri. Setelah disuspensikan, sebanyak 6 sumuran dibuat dengan diameter $5 \mathrm{~mm}$. Sumuran yang telah dibuat diisi dengan 6 formula yogurt sebanyak $0,5 \mathrm{~mL}$ dan 
dibiarkan meresap selama \pm 30 menit. Selanjutnya media diinkubasi dengan suhu $37{ }^{\circ} \mathrm{C}$ selama 24 jam. Amati terjadinya daerah bening di sekitar sumuran sebagai daerah hambat yang diberikan oleh yogurt (Susanti et al., 2007).

\section{Analisis Data}

Penelitian ini merupakan penelitian berjenis eksperimental dengan 3 kali pengulangan. Perlakuan yang bertujuan untuk mencari komposisi optimal dari kombinasi bakteri Lactobacillus bulgaricus dan Streptococcus thermophilus pada fermentasi yogurt yang terfortifikasi buah lakum tersebut didasarkan pada standar mutu SNI produk yogurt, keasaman, $\mathrm{pH}$, kadar antosianin dan aktivitas daya hambat pada Escherichia coli. Analisis data menggunakan MANOVA(Multivariate Analysis of Variance) dengan taraf signifikansi 95\%.

\section{HASIL DAN PEMBAHASAN}

Yogurt dibuat dengan menggunakan susu bubuk full cream yang dipasteurisasi dan diberikan perlakuan variasi komposisi bakteri L. Bulgaricus dan Streptococcus thermophilus (1:1, 1:2 dan 2:1), serta dengan penambahan ekstrak lakum. Formula yogurt dapat dilihat pada Tabel 1. Yogurt dibuat dengan memfermentasi susu pada suhu $37{ }^{\circ} \mathrm{C}$ selama 18 jam. Buah lakum yang digunakan pada penelitian ini dan contoh produk yogurt dengan komposisi bakteri L. bulgaricus dan S. thermophilus 2:1 masing-masing dapat dilihat di Gambar 1 dan 2 . Ekstrak lakum dibuat dengan menghaluskan buah lakum dan dipanaskan pada suhu $70{ }^{\circ} \mathrm{C}$ selama 120 menit dan didapat ekstrak sebanyak 237,61 gram. Ekstrak lakum berbentuk cair dan berwarna merah keunguan.

\section{Nilai pH}

Proses fermentasi yang terjadi pada yogurt adalah perubahan komponen susu menjadi metabolit akhir yaitu terbentuknya asam laktat, yang menyebabkan naiknya nilai keasaman dan terjadi penurunan $\mathrm{pH}$ yogurt, yang dapat dilihat pada parameter penurunan $\mathrm{pH}$. Menurut Buckle et al (2007), pH yogurt berada di sekitar 4,0-4,5.
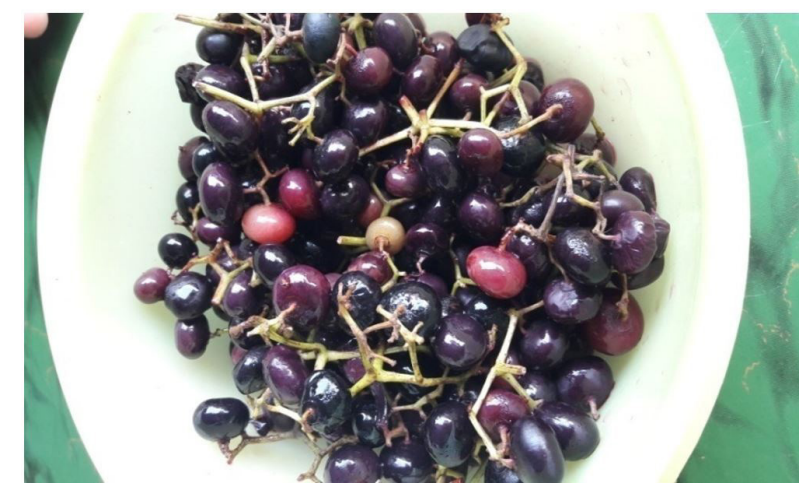

Gambar 1. Buah lakum (Cayratia trifolia (L.) Domin)
Nilai $\mathrm{pH}$ yogurt yang dihasilkan pada penelitian ini dapat dilihat pada Tabel 2. Pada hari ke-0, pH berkisar antara 3,65-4,02. Pada hari ke-28, $\mathrm{pH}$ yogurt berkisar antara $3,53-4,83$. Terdapat perbedaan yang signifikan antara variasi komposisi bakteri terhadap $\mathrm{pH}(\mathrm{p}<0,05)$. Pada yogurt dengan perbandingan kombinasi L. bulgaricus dan $S$. thermophilus 2:1, $\mathrm{pH}$ yogurt mengalami penurunan sampai hari ke-14 dan mulai terlihat kenaikan $\mathrm{pH}$ pada hari ke-21. Penurunan $\mathrm{pH}$ dapat disebabkan banyaknya $L$. bulgaricus yang terdapat di yogurt. $L$. bulgaricus memetabolisme laktosa menjadi asam laktat. Asam laktat $\left(\mathrm{C}_{3} \mathrm{H}_{6} \mathrm{O}_{3}\right)$ mudah terdisosiasi menjadi ion $\mathrm{H}^{+}$ dan $\mathrm{CH}_{3} \mathrm{CHOHCOO}^{-}$. Faktor lain yang mempengaruhi penurunan $\mathrm{pH}$ selama penyimpanan adalah karena adanya penambahan ekstrak lakum. Kandungan laktosa dari ekstrak lakum akan diubah oleh L. bulgaricus menjadi asam laktat yang berakibat dengan turunnya nilai $\mathrm{pH}$ yogurt (Umela, 2017). Pada penyimpanan yogurt hari ke-28, terjadi kenaikan nilai $\mathrm{pH}$ yang disebabkan adanya basa alami aktivitas proteolitik yang terjadi dalam yogurt (Chandan, 2014).

\section{Total Asam}

Keasaman atau total asam tertitrasi adalah jumlah asam yang dihitung sebagai asam laktat. Parameter keasaman umumnya berbanding terbalik dengan $\mathrm{pH}$. Meningkatnya nilai asam terjadi seiring dengan menurunnya nilai $\mathrm{pH}$. Keasaman pada produk yogurt dinyatakan dalam persen yaitu antara 0,5-2\% (SNI, 2009). Keasaman yogurt yang dibuat pada penelitian ini telah sesuai dengan standar SNI yaitu 0,7-0,8\%. Dari Tabel 3, dapat dilihat bahwa variasi komposisi bakteri berpengaruh secara signifikan $(\mathrm{p}<0,05)$ terhadap keasaman. Pada yogurt tanpa ekstrak, kadar keasaman paling tinggi ada pada komposisi L. bulgaricus dan S. thermophilus 2:1. Hal ini karena sifat bakteri yang homofermentatif pada proses fermentasi akan menghasilkan asam laktat yang mempengaruhi penurunan $\mathrm{pH}$ sehingga menyebabkan peningkatan keasaman pada yogurt (Umela, 2017). Asam laktat $\left(\mathrm{C}_{3} \mathrm{H}_{6} \mathrm{O}_{3}\right)$ mudah terdisosiasi menjadi ion $\mathrm{H}^{+}$dan $\mathrm{CH}_{3} \mathrm{CHOHCOO}^{-}$. Pengukuran dengan $\mathrm{pH}$ meter hanya untuk mengetahui jumlah asam terdisosiasi. Sedangkan pada nilai keasaman, nilai yang terukur adalah semua komponen asam, baik yang terdisosiasi maupun yang tidak (Sah et al., 2016). Peningkatan keasaman juga terjadi pada yogurt dengan tambahan ekstrak buah lakum. Hal ini karena dengan adanya ekstrak yang mengandung laktosa, maka bakteri asam laktat juga akan mengubah laktosa menjadi asam laktat yang meningkatkan keasaman. Hasil ini sejalan dengan penelitian Jung et al (2016) yang menyatakan bahwa dengan penambahan ekstrak, maka keasaman yogurt akan meningkat. Lamanya penyimpanan juga berpengaruh signifikan terhadap keasaman karena selama penyimpanan masih terjadi proses fermentasi meskipun lambat sehingga viabilitas BAL (bakteri asam 


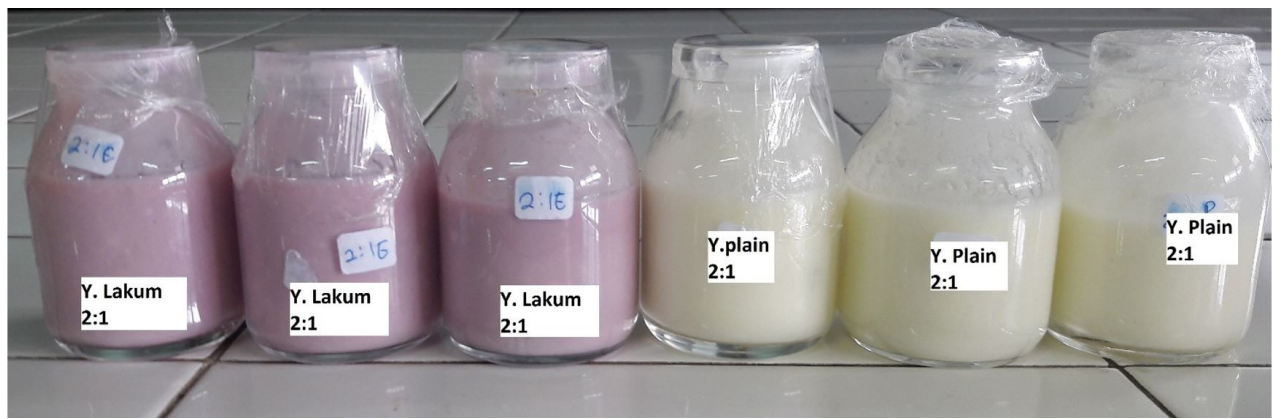

Gambar 2. Yogurt dengan perbandingan komposisi bakteri LB dan ST 2:1

Tabel 2. Hasil pengujian pengaruh variasi kombinasi Lactobasillus bulgaricus dan Streptococcus thermophilus pada yogurt yang difortifikasi buah lakum terhadap $\mathrm{pH}$ pada berbagai masa penyimpanan

\begin{tabular}{llllll}
\hline \multirow{2}{*}{ Formula } & \multicolumn{5}{c}{ Nilai pH } \\
\cline { 2 - 6 } & $\mathrm{H} 0$ & $\mathrm{H} 7$ & $\mathrm{H} 14$ & $\mathrm{H} 21$ & $\mathrm{H} 28$ \\
\hline Plain 1:1 & $3,99 \pm 0,02^{\mathbf{f D}}$ & $4,03 \pm 0,06^{\mathbf{f B}}$ & $4,23 \pm 0,06^{\mathbf{f A}}$ & $4,57 \pm 0,06^{\mathbf{f C}}$ & $4,83 \pm 0,06^{\mathbf{f E}}$ \\
Plain 1:2 & $4,02 \pm 0,02^{\mathbf{e D}}$ & $4,01 \pm 0,11^{\mathbf{e B}}$ & $3,93 \pm 0,06^{\mathbf{e A}}$ & $4,21 \pm 0,02^{\mathrm{eC}}$ & $4,31 \pm 0,01^{\mathbf{e E}}$ \\
Plain 2:1 & $3,94 \pm 0,04^{\mathbf{c D}}$ & $3,92 \pm 0,04^{\mathbf{c B}}$ & $3,71 \pm 0,01^{\mathbf{c A}}$ & $3,51 \pm 0,02^{\mathbf{c C}}$ & $3,89 \pm 0,02^{\mathbf{c E}}$ \\
Lakum 1:1 & $3,81 \pm 0,01^{\mathbf{d D}}$ & $3,69 \pm 0,01^{\mathbf{d B}}$ & $3,77 \pm 0,06^{\mathbf{d A}}$ & $3,87 \pm 0,06^{\mathbf{d C}}$ & $4,05 \pm 0,05^{\mathbf{d E}}$ \\
Lakum 1:2 & $3,71 \pm 0,01^{\mathbf{b D}}$ & $3,52 \pm 0,03^{\mathbf{b B}}$ & $3,41 \pm 0,01^{\mathbf{b A}}$ & $3,61 \pm 0,02^{\mathbf{b C}}$ & $3,76 \pm 0,03^{\mathbf{b E}}$ \\
Lakum 2:1 $^{3,65 \pm 0,02^{\mathbf{a D}}}$ & $3,51 \pm 0,01^{\mathbf{a B}}$ & $3,41 \pm 0,01^{\mathbf{a A}}$ & $3,31 \pm 0,01^{\mathbf{a C}}$ & $3,53 \pm 0,05^{\mathbf{a E}}$ \\
\hline
\end{tabular}

Keterangan: Huruf kecil (a-f) superscript yang berbeda dalam satu kolom menunjukkan variasi bakteri berpengaruh sangat nyata $(\mathrm{P}<0,01)$ terhadap nilai $\mathrm{pH}$, sedangkan huruf kecil yang sama menunjukkan variasi bakteri tidak berpengaruh nyata $(\mathrm{P}>0,05)$ terhadap nilai $\mathrm{pH}$.

laktat) meningkat yang menyebabkan keasaman juga meningkat (Chandan, 2014).

\section{Total Antosianin Esktrak Lakum}

Pengukuran total antosianin menggunakan metode $\mathrm{pH}$ differential (Jie et al., 2013). Hasil uji total antosianin ekstrak lakum 7,5\% pada hari pertama adalah sebesar $61,73 \mathrm{mg} / \mathrm{L}$. Selama penyimpanan, total antosianin dari ekstrak mengalami penurunan kadar. Hal ini karena terjadinya degradasi sifat antosianin yang sangat tergantung pada oksigen, enzim, cahaya, lingkungan, suhu dan pH (Andarwulan \& Faradila, 2012). Variasi komposisi bakteri berpengaruh secara signifikan terhadap kadar antosianin dalam yogurt. Demikian pula selama penyimpanan, terjadi perubahan yang signifikan terhadap kadar antosianin yang dapat dilihat pada Tabel 4. Penghitungan total antosianin pada ekstrak buah lakum pada penelitian ini tidak dikondisikan pada lingkungan dengan $\mathrm{pH}$ rendah, dengan pemberian larutan alkali, atau dengan penambahan zat oksidator. Hal ini merupakan faktor penyebab terjadinya penurunan total antosianin pada ekstrak lakum selama penyimpanan. Kadar antosianin tertinggi terdapat pada yogurt dengan komposisi L. bulgaricus dan S. thermophilus 2:1. Hal ini disebabkan oleh aktivitas bakteri asam laktat yang menyebabkan $\mathrm{pH}$ rendah dan keasaman tinggi. Ini memberikan lingkungan yang baik untuk penyimpanan antosianin dengan $\mathrm{pH}$ lingkungan yang rendah sehingga antosianin cukup stabil pada formula $2: 1$.

\section{Daya Hambat Terhadap E.coli}

Pengujian daya hambat formula yogurt terhadap bakteri $E$. coli dilakukan dengan menggunakan metode sumuran. Diameter daya hambat (Gambar 3) berkisar antara 2,3-3,4 $\mathrm{mm}$. Daya hambat terbesar dan yang memberikan perbedaan signifikan adalah formula yogurt 2:1 tanpa ekstrak lakum. Pengaruh lama penyimpanan

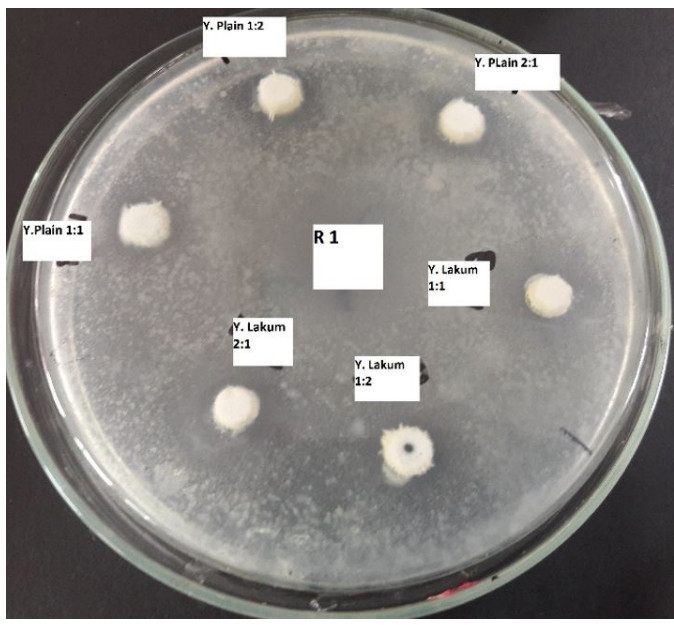

Gambar 3. Diameter daya hambat yogurt terhadap $\boldsymbol{E}$. coli 
Tabel 3. Hasil pengujian pengaruh variasi kombinasi Lactobacillus bulgaricus dan Streptococcus thermophilus pada yogurt yang difortifikasi buah lakum terhadap total asam pada berbagai masa penyimpanan

\begin{tabular}{lccccc}
\hline \multirow{2}{*}{ Formula } & \multicolumn{5}{c}{ Total asam (\%) } \\
\cline { 2 - 6 } & H0 & H7 & H14 & H21 & H28 \\
\hline Plain 1:1 & $0,705 \pm 0,003^{\mathrm{aD}}$ & $0,708 \pm 0,007^{\mathrm{aC}}$ & $0,682 \pm 0,002^{\mathrm{aA}}$ & $0,663 \pm 0,002^{\mathrm{aB}}$ & $0,636 \pm 0,002^{\mathrm{aE}}$ \\
Plain 1:2 & $0,746 \pm 0,009^{\mathrm{bD}}$ & $0,750 \pm 0,003^{\mathrm{bC}}$ & $0,772 \pm 0,003^{\mathrm{bA}}$ & $0,750 \pm 0,002^{\mathrm{bB}}$ & $0,708 \pm 0,002^{\mathrm{bE}}$ \\
Plain 2:1 & $0,768 \pm 0,002^{\mathrm{dD}}$ & $0,773 \pm 0,01^{\mathrm{dC}}$ & $0,815 \pm 0,002^{\mathrm{dA}}$ & $0,831 \pm 0,002^{\mathrm{dB}}$ & $0,777 \pm 0,009^{\mathrm{dE}}$ \\
Y. Lakum 1:1 & $0,773 \pm 0,006^{\mathrm{cD}}$ & $0,770 \pm 0,01^{\mathrm{cC}}$ & $0,768 \pm 0,002^{\mathrm{cA}}$ & $0,764 \pm 0,003^{\mathrm{cB}}$ & $0,731 \pm 0,002^{\mathrm{cE}}$ \\
Y. Lakum 1:2 & $0,792 \pm 0,002^{\mathrm{eD}}$ & $0,804 \pm 0,002^{\mathrm{eC}}$ & $0,847 \pm 0,002^{\mathrm{eA}}$ & $0,797 \pm 0,003^{\mathrm{eB}}$ & $0,770 \pm 0,003^{\mathrm{eE}}$ \\
Y. Lakum 2:1 & $0,809 \pm 0,007^{\mathrm{fD}}$ & $0,824 \pm 0,01^{\mathrm{fC}}$ & $0,866 \pm 0,004^{\mathrm{fA}}$ & $0,886 \pm 0,003^{\mathrm{fB}}$ & $0,836 \pm 0,003^{\mathrm{fE}}$ \\
\hline
\end{tabular}

Keterangan: Huruf kecil (a-f) superscript yang berbeda dalam satu kolom menunjukkan variasi bakteri berpengaruh sangat nyata $(\mathrm{P}<0,01)$ terhadap kadar total asam, sedangkan huruf kecil yang sama menunjukkan variasi bakteri tidak berpengaruh nyata $(\mathrm{P}>0,05)$ terhadap kadar total asam.

Huruf kapital (A-F) superscript yang berbeda dalam satu baris menunjukkan lama penyimpanan berpengaruh sangat nyata $(\mathrm{P}<0,01)$ terhadap kadar total asam, sedangkan huruf kapital yang sama menunjukkan lama penyimpanan tidak berpengaruh nyata $(\mathrm{P}>0,05)$ terhadap kadar total asam

Tabel 4. Hasil pengujian pengaruh variasi kombinasi starter bakteri Lactobacillus bulgaricus dan Streptococcus thermophilus pada yogurt yang difortifikasi buah lakum terhadap total antosianin pada berbagai masa penyimpanan

\begin{tabular}{|c|c|c|c|c|c|}
\hline \multirow{2}{*}{ Formula } & \multicolumn{5}{|c|}{ Total antosianin $(\mathrm{mg} / \mathrm{L})$} \\
\hline & HO & H7 & H14 & H21 & H28 \\
\hline Ekstrak Lakum 7,5\% & $61,73 \pm 1,13^{\mathrm{e}}$ & $56,00 \pm 1,60^{d}$ & $46,90 \pm 1,62^{\mathrm{c}}$ & $36,93 \pm 0,08^{b}$ & $28,92 \pm 0,63^{\mathrm{a}}$ \\
\hline Y. Lakum 1:1 & $46,17 \pm 1,4^{\mathrm{bE}}$ & $42,94 \pm 0,2^{\mathrm{bD}}$ & $40,36 \pm 1,6^{\mathrm{bC}}$ & $32,23 \pm 3,6^{\mathrm{bB}}$ & $26,83 \pm 2,5^{\mathrm{bA}}$ \\
\hline Y. Lakum 1:2 & $35,87 \pm 1,4^{\mathrm{aE}}$ & $31,28 \pm 0,8^{\mathrm{aD}}$ & $30,84 \pm 0,5^{\mathrm{aC}}$ & $23,66 \pm 0,9^{\mathrm{aB}}$ & $21,12 \pm 0,9^{\mathrm{aA}}$ \\
\hline Y. Lakum 2:1 & $50,51 \pm 0,2^{\mathrm{cE}}$ & $45,20 \pm 0,7^{\mathrm{cD}}$ & $41,86 \pm 0,1^{\mathrm{cC}}$ & $36,18 \pm 2,6^{\mathrm{cB}}$ & $30,98 \pm 1,5^{\mathrm{cA}}$ \\
\hline
\end{tabular}

Keterangan: Huruf kecil (a-c) superscript yang berbeda dalam satu kolom menunjukkan variasi bakteri berpengaruh sangat nyata $(\mathrm{P}<0,01)$ terhadap total antosianin ekstrak lakum, sedangkan huruf kecil yang sama menunjukkan variasi bakteri tidak berpengaruh nyata $(\mathrm{P}>0,05)$ terhadap total antosianin ekstrak lakum.

Huruf kapital (A-F) superscript yang berbeda dalam satu baris menunjukkan lama penyimpanan berpengaruh sangat nyata $(\mathrm{P}<0,01)$ terhadap total antosianin ekstrak lakum, sedangkan huruf kapital yang sama menunjukkan lama penyimpanan tidak berpengaruh nyata $(\mathrm{P}>0,05)$ terhadap total antosianin.

terhadap daya hambat dapat dilihat pada Tabel 5. Selama penyimpanan, tidak terjadi perubahan yang signifikan terhadap daya hambat yogurt pada hari ke-7, ke-14 dan ke21. Pada Tabel 5, terlihat pada hari ke-7 bahwa rata-rata formula memberikan peningkatan daya hambat dan mulai terjadi penurunan pada hari ke-21. Menurut Akpinar et al (2011), adanya metabolit yang dihasilkan oleh bakteri asam laktat, seperti asam laktat, hidrogen peroksida dan bakteriosin, diduga dapat menghambat pertumbuhan bakteri patogen. L. bulgaricus menghasilkan metabolit berupa asam laktat, hidrogen peroksida dan bakteriosin. Sifat asam laktat adalah mudah larut dalam air sehingga dapat dengan mudah berpenetrasi ke dalam sel bakteri. Ini akan merusak membran luar bakteri Gram negatif dan menyebabkan bakteriosin, $\mathrm{H}_{2} \mathrm{O}_{2}$ dan antimikroba lain dapat masuk ke dalam membran sitoplasma sehingga dapat menghambat bakteri Gram negatif (Alokomi et al., 2000). Jumlah L. bulgaricus yang banyak juga menyebabkan $\mathrm{pH}$ menjadi asam, sedangkan bakteri $E$. coli tidak tahan terhadap suasana asam. Menurut Guraya et al (1998), bakteri Gram negatif tidak tahan terhadap lingkungan asam. Hal ini dapat dilihat bahwa naiknya daya hambat bakteri sejalan dengan turunnya nilai $\mathrm{pH}$ dan meningkatnya keasaman.

\section{KESIMPULAN}

Yogurt yang terfortifikasi ekstrak buah lakum (Cayratia trifolia (L.) dengan variasi $L$. bulgaricus dan $S$. ermophilus 2:1 memberikan stabilitas yang baik selama penyimpanan dengan nilai keasaman yang meningkat dan $\mathrm{pH}$ yang turun. Hasil analisis antosianin dalam yogurt selama penyimpanan menunjukkan bahwa kadar antosianin mengalami penurunan. Pada pengujian daya hambat terhadap bakteri E. coli, yogurt plain (tanpa ekstrak buah lakum) dengan kombinasi L. bulgaricus 
Tabel 5. Hasil pengujian pengaruh variasi kombinasi starter bakteri Lactobacillus bulgaricus dan Streptococcus thermophilus pada yogurt yang difortifikasi buah lakum terhadap daya hambat pada berbagai masa penyimpanan

\begin{tabular}{llllll}
\hline \multirow{2}{*}{ Formula } & \multicolumn{5}{c}{ Diameter daya hambat $(\mathbf{m m})$} \\
\cline { 2 - 6 } & $\mathbf{H 0}$ & $\mathbf{H 7}$ & $\mathbf{H 1 4}$ & $\mathbf{H 2 1}$ & $\mathbf{H 2 8}$ \\
\hline plain 1:1 & $2,8 \pm 0,5^{\mathrm{aB}}$ & $3,0 \pm 1,0^{\mathrm{aC}}$ & $3,0 \pm 0,0^{\mathrm{aC}}$ & $3,2 \pm 0,4^{\mathrm{aC}}$ & $2,3 \pm 0,6^{\mathrm{aA}}$ \\
plain 1:2 & $3,1 \pm 0,5^{\mathrm{cB}}$ & $3,7 \pm 0,6^{\mathrm{cC}}$ & $3,7 \pm 0,3^{\mathrm{cC}}$ & $3,3 \pm 0,6^{\mathrm{cC}}$ & $2,7 \pm 0,3^{\mathrm{cA}}$ \\
plain 2:1 & $3,4 \pm 0,4^{\mathrm{cB}}$ & $3,8 \pm 0,8^{\mathrm{cC}}$ & $3,7 \pm 0,6^{\mathrm{cC}}$ & $3,8 \pm 0,3^{\mathrm{cC}}$ & $2,3 \pm 0,2^{\mathbf{c A}}$ \\
Y Lakum 1:1 & $2,3 \pm 0,1^{\mathrm{aB}}$ & $3,3 \pm 0,6^{\mathrm{aC}}$ & $2,8 \pm 0,6^{\mathrm{aC}}$ & $2,3 \pm 0,6^{\mathrm{aC}}$ & $1,8 \pm 0,4^{\mathrm{aA}}$ \\
Y Lakum 1:2 $^{\mathrm{a}}$ & $2,3 \pm 0,6^{\mathrm{aB}}$ & $3,0 \pm 0,0^{\mathrm{aC}}$ & $3,7 \pm 0,3^{\mathrm{aC}}$ & $3,5 \pm 0,5^{\mathrm{aC}}$ & $2,1 \pm 0,2^{\mathrm{aA}}$ \\
Y Lakum 2:1 $^{3}$ & $3,0 \pm 1,0^{\mathbf{b B}}$ & $3,7 \pm 0,4^{\mathrm{bC}}$ & $3,8 \pm 0,3^{\mathrm{bC}}$ & $3,2 \pm 0,2^{\mathrm{bC}}$ & $2,3 \pm 0,6^{\mathrm{bA}}$ \\
\hline
\end{tabular}

Keterangan: Huruf kecil (a-f) superscript yang berbeda dalam satu kolom menunjukkan variasi bakteri berpengaruh sangat nyata $(\mathrm{P}<0,01)$ terhadap daya hambat, sedangkan huruf kecil yang sama menunjukkan variasi bakteri tidak berpengaruh nyata $(\mathrm{P}>0,05)$ terhadap daya hambat. Huruf kapital (A-F) superscript yang berbeda dalam satu baris menunjukkan lama penyimpanan berpengaruh sangat nyata $(\mathrm{P}<0,01)$ terhadap daya hambat, sedangkan huruf kapital yang sama menunjukkan lama penyimpanan tidak berpengaruh nyata $(\mathrm{P}>0,05)$ terhadap daya hambat.

dan S. termophilus 2:1 memberikan daya hambat yang paling tinggi. Penelitian lebih lanjut mengenai parameter kualitas yogurt, seperti viabilitas bakteri asam laktat dan kadar laktosa, serta pengujian aktivitas antibakteri terhadap bakteri patogen lain, misalnya Staphylococcus aureus, perlu dilakukan di masa mendatang.

\section{UCAPAN TERIMA KASIH}

Penulis menyampaikan terima kasih kepada Akademi Farmasi Yarsi Pontianak atas dukungan dan dana selama penelitian. Penulis juga menyampaikan terima kasih sebesar-besarnya kepada Ibu Nurkhasanah dan Ibu Ika Dyah atas dukungan moral dan material sehingga penelitian ini berjalan lancar.

\section{DAFTAR ACUAN}

Akpinar, A., Yerlikaya, A. \& Kilic, S. (2011). Antimicrobial activity and antibiotic resistance of Lactobacillus delrubeckii ssp.bulgaricus and Streptococcus termophilus strain isolated from Turkish homemade yoghurts. African Journal of Microbiology Research, 5(6), 675-682

Alokomi, H.L., Skytta, E. \& Sarella, M. (2000). Lactic acid permeabilizes Gram negative bacteria by distrupting outer membrane. Applied and Environmental Microbiology, 66: 2001-2005

Andarwulan, N. \& Faradilla., R.H.F. (2012). Pewarna Alami Untuk Pangan, (SEAFAST) Center, Institut Pertanian Bogor

Association of Official Analitical Chemist (AOAC). (1995). Official Metods of Analitical Chemist. Vol. IA.
AOAC, Inc., Washington

Badan Pengawas Obat dan Makanan (BPOM). (2005). Ketentuan Pokok Pangan Fungsional., PerKa BPOM Nomor HK 00.05.52.0685

Buckle, K.A., Edward, R.A., Fleet, G.H. \& Wotton, M. (2007). Ilmu Pangan, diterjemahkan oleh Pornomo, H dan Adiono, Universitas Indonesia Press. Jakarta

Chandan, R.C. \& Shahani, K.M. (1993). Yogurt. In: Y. H. Hui. Dairy Science and Technology Handbook. 2. Product Manufacturing, VCH Pub. Inc., USA

Guraya, R., Frank. J.F. \& Hasan, A.N. (1998). Effectiveness of salt, $\mathrm{pH}$ and diacetyl as inhibitors of Escherichia coli $0157: \mathrm{H} 7$ in dairy foods stored at refrigeration temperatures. Journal of Food Protection, 61: 1098-1102.

Helferich, W. \& Westhoff, D. (1980). All About Yogurt, Englewood Cliff, New Jersey

Jung, J., Paik, H.D., Yoon, H.J., Jang, H.J., Jeewanthi, R.K.C., Jee, H.S., Li, X., Lee, N.-K. \& Lee, S.K. (2016). Physicochemical characteristics and antioxidant capacity in yogurt fortified with red ginseng extract. Korean Journal for Food Science of Animal Resources, 36(3): 412-420

Jie, L., Xiao-ding, L., Yun, Z., Zheng-dong, Z., Zhi-ya, Q., Meng, L., Shao-hua, Z., Shou, L., Wang, M. \& Lu, Q. (2013). Identification and thermal stability of purplefleshed sweet potato anthocyanins in aqueous solutions with various $\mathrm{pH}$ values and fruit juices, Food Chem., 136: $1429-1434$ 
Kumar, D., Gupta, J., Kumar, S., Arya, R., Kumar, T. \& Gupta, A. (2012). Pharmacognostic evaluation of Cayratia trifolia (Linn). leaf. Asian Pasific Journal of Topical Biomedecine, 2: 6-10

Mitchel, L.R. \& Sandine, W.E. (1984). Associative growth and differential enumeration of $S$. thermopilus and L. bulgaricus. Journal Food Potection, 47: 245-248

Neliyanti \& Idiawati, N. (2014). Ekstraksi dan uji stabilitas zat warna alami dari buah lakum (Cayratia trifolia (L) Domin). J. Kim. Khatulistiwa, 3(2): 86-93

Sah, B.N.P., Vasiljevik, T., McKenchnie, S. \& Donkron, O.N. (2016). Physicochemical, textural and rheological properties of probiotic yogurt fortified with fibre rich pineapple peel powder during refrigerated storage. $L W T$ Food Science and Technology, 65: 978-986

Sowmya, S., Perumal, P.C., Anusooriya, P., Vidya, B., Pratibha, P., Malarvizhi, D. \& Gopalakrihnam, V.K. (2015). Comparative preliminary phytochemical analysis various different parts (stem, leaf and fruit) of Cayratia trifolia (L.). Indo-Am. J. Pharm. Res., 5: 218-23
Standar Nasional Indonesia (SNI). (1992). SNI : Nomor 01-2981-1992 Tentang Yogurt. Jakarta

Susanti, I., Kusumaningtyas, R.W. \& Illanigtyas, F. (2007). Uji sifat probiotik bakteri asam laktat sebagai kandidat bahan pangan fungsional. Jurnal Teknologi dan Industri Pangan, 18(2)

Trachoo, N. (2002). Review article: Yogurt: The fermented milk, Songklanakrin J. Sci. Technol., 24(4) Oct-Des

Umela, S. (2017). Variasi konsentrasi starter Lactobacillus bulgaricus dan Streptococcus thermophilus terhadap karakteristik yogurt jagung pulut., Journal of Argitech. Science, 1 (2) Nov

Winarno. F.G., \& Winarno, W. (2017). Mikrobioma Usus. Gramedia Pustaka Utama. Jakarta. 